\title{
Malignant Mediastinal Germ Cell Tumor
}

National Cancer Institute

\section{Source}

National Cancer Institute. Malignant Mediastinal Germ Cell Tumor. NCI Thesaurus. Code C6446.

An extragonadal malignant germ cell tumor that arises from the mediastinum. This category includes seminoma, embryonal carcinoma, yolk sac tumor, choriocarcinoma, mixed germ cell tumors, and immature malignant teratoma. 